\title{
1. Being Spanish in the Early Modern World
}

\author{
Alexander Samson
}

\begin{abstract}
This chapter explores the limits and frontiers of Spain and Spanishness in the sixteenth and early seventeenth centuries from temporal, political and geographical perspectives. The global displacements and mobility of the peoples who came to be described as 'Spanish' across this period, their state of estrangement and motion as a structuring condition of identity, formed a crucial driver of the negotiations, political, cultural and linguistic, which came to define 'Spain'. From the racial politics of Latin America to the states of the Hispanic monarchy whose link to Spain was mediated by foreign Habsburg dynasts, the foreign/other was always a fundamental part of the web of exchanges and interchangeability that made Spain different, an object of envy and admiration from within and without.
\end{abstract}

Keywords: Spanish, identity, Hispanophilia, Hispanophobia, exomorphism

This chapter seeks to explore what it meant to be Spanish in the early modern period, both for those defining themselves in this way and those describing others as such. It explores how 'Spain' emerged from tensions between cosmopolitan and rooted accounts of belonging, from broader or narrower geographical or political frames, differing understandings of allegiance as territorial, civic or dynastic, and attempts to circumscribe and police religious, political, linguistic and cultural limits. These tensions expressed themselves in the contradiction between a desire to engage with the world and the fear of contaminating difference, seen most notably in relation to the anxieties concerning Spain's religious minorities. Raising Spanishness as a question in this period immediately runs the risk of anachronism, employing a category whose modern meaning is ultimately

Rodríguez Pérez, Y. (ed.), Literary Hispanophobia and Hispanophilia in Britain and the Low Countries (1550-1850). Amsterdam: Amsterdam University Press, 2020 DOI 10.5117/9789462989375_CHO1 
rooted in the system of nation states that emerged in the nineteenth century as Europe was distilled from 500 discrete political entities into just 25 or so nation states by the dawn of the twentieth century. ${ }^{1}$ Beyond presupposing and so reifying the object of enquiry, a series of historical elisions with important contemporary implications also lurk at the heart of the term 'Spain', imprecisions and generalizations like, for example, its conflation with Castile, glossing over important internal divisions and differences of language and culture apparent in regional 'nationalisms' from the Basque country to Catalunya. The mixed feelings evoked by Spain when it sat at the heart of the Hispanic monarchy three centuries ago reflect both the extent to which its various subjects embraced the imperial project that came to define the monarchy especially in the eyes of others, and how they responded to the inevitable opprobrium that this global reach and power brought. At the heart of what came to define Spain was a tension between inclusive and exclusionary ideas about those who should or should not be dubbed 'españoles'.

Borders and frontiers between states in the early modern period emerged locally from custom and collective memory, expressed in myriad quotidian interactions between individual subjects tracing and retracing their situation in sanctioned behaviours. On the other hand, abstract mathematical and cartographic methods for measuring space, the rise of surveying and chorography, came to influence how divisions were conceptualized. ${ }^{2}$ Natural frontiers like rivers or mountains could be as much routes of transmission and circulation, linking and bridging, as barriers dividing. Multiple, competing jurisdictions overlaid mosaics of land ownership, ecclesiastical jurisdictions, and overlapping dues, rights, privileges and acts of obeisance. By reaching across territorial divisions, these relations of a personal rather than political nature blurred and confused definitions of place. These processes were part of a broader territorialization, by means of which measure and control coalesced, combining technical and legal competencies to produce land, as opposed to people, under the dominion of a single ruling authority. ${ }^{3}$

The variegated nature of Iberian territory even in the sixteenth century is well illustrated by the bitter complaint of John Briertonne, on the border between Aragón and Castile on 23 June 1537. Travelling in the company of Henry VIII's ambassador Thomas Wyatt the elder to the imperial court, he recounted in a letter to Thomas Wriothesley from Valladolid that: 
we came into a Citie called Seragoza, where we were extremely handled as though we had been Jews. All our caringe was had home to the serch house, where al my Master's apparail and the gentlemens, with the rest of the servaunts were searched to th'uttermost. They made us pay for all things that were unworne. They be the spitefullest people in the world. ${ }^{4}$

To Wyatt's pleas of diplomatic immunity the customs officials responded that 'if Christ or Sanct Fraunces came with all their flock they shuld not eskape'.5 Briertonne then related that the empress had sent by post in a little box to Barcelona a silk flower she had made for the emperor and that Zaragoza's customs officials had not allowed it to pass unsearched, even for the hundred ducats offered to them by the messenger: they 'set as much by th'Emperor lettres as they doo by myne. ${ }^{6}$ Despite the awesome power Charles V enjoyed, apparent in the fears of rivals like France, he was still subject to the jurisdictions, privileges and customs of each and every one of the territories he ruled. Land became a political entity only as monarchies developed centralized, representative strategies that enabled effective control over extended space, an evolution in which cities, as in the example here, were fundamental underlying structures of 'empire' both in Spain and the Americas. ${ }^{7}$ Most of the area ruled by Spain consisted of 'vast expanses of administratively empty space', lying between urban nodes bound together in loose networks where authority was largely 'interpersonal, non-territorial'. 8 Personal fealty to the king lay at the heart of belonging, and while this was the case, Habsburg dynasts were forced to confront and contain the multifarious tensions between the constituent territories that made up their 'empire. ${ }^{9}$ Tellingly, the Habsburg dynasts are referred to in Spain today as 'os Austrias', in a peculiar gesture of geographical self-estrangement. The year 1640 saw a powerful reassertion of local identities as against imperial claims, with the Revolt of the Catalans and Portugal's successful reassertion of sovereign independence, both reacting against Olivares's attempts to enforce greater unity and homogeneity through the mutual defence pact, dubbed the Union of Arms. ${ }^{10}$

4 Muir, Life and Letters of Sir Thomas Wyatt, p. 44.

5 Ibid.

6 Ibid.

7 See Espinosa, The Empire of the Cities.

8 Biedermann, (Dis)connected Empires, pp. 25 and 36 .

9 This is itself merely a convenient shorthand. There never was a 'Spanish empire' as Anthony Pagden has said, rather 'a confederation of principalities held together in the person of a single king' (see Pagden, Spanish Imperialism and the Political Imagination, p. 3).

10 Feros, Speaking of Spain, p. 49. 
Shortly after Philip II married Mary I on 25 July 1554, the feast day of Spain's patron saint, Santiago, adding yet another major dynastic union to the bewildering conglomeration of states that had already come into Habsburg hands as a result of the miraculous inheritance of his father Charles V, the Earl of Westmorland, Henry Neville, asserted 'I am and shall be a Spaniard to the uttermost of my power. ${ }^{11}$ His imagined transcendence of patriotic localism through allegiance to his new king reflected the universalist idealism implicit in dynastic politics. It underlines the elasticity of the term 'Spanish', where it is invoked exclusively in relation to personal allegiance to a ruler. Philip playfully began signing himself king of England before he had even set foot there. He consciously cultivated an English persona when he did and was soon hailed by his English subjects as English and not Spanish. The queen's chaplain John Christoferson suggested in similar terms:

the Quenes grace taketh no straunger to marry wyth, but such one as both by father and mother cometh of the royall bloude of Englande, and nowe at lengthe is called home, as it were to hys natyue countrye, insomuch that no true Englishe man hath any cause to grudge at the matter, but great cause hath he to merueyle at the wonderfull prouidence of god therin, and hartely to thanke him to, that he of hys goodnes both hath so auaunced the noble bloude of Englande abroad in the worlde. ${ }^{12}$

Mary I's reputation and place in Tudor history is forever tainted by her Spanish heritage. On the one hand, she was accused by opponents of being too 'Spanish' and overly attached to Spain, while, on the other, her supporters claimed Philip II for England. The association with Spain, however, over time posthumously extended to her the cruelty and tyranny with which their empire came to be associated, and was incarnated ultimately in her epithet, Bloody. The Anglo-Spanish alliance illustrates two opposing responses to difference, its transcendence by underlining plasticity and multiplicity, or its erasure through annihilation or assimilation. Philip's conscious selffashioning in England built on lessons his father had learnt in Spain, where his Burgundian advisors' tactless handling of his accession and assumption of power had provoked a major revolt. The gifting of important offices, lack of access and attempt to impose taxes to pay for bribes for the imperial electors fomented the perception of his Flemish and Burgundian advisors as venial, predatory interlopers damaging the interests of native-born subjects. Fray 
Alonso de Castrillo's Tractado de república (1521), published as the revolt was brought to an end by a fragile coalition of royal and landed aristocratic interests, blamed foreigners for the civil conflict:

novelties and the most scandalous counsels seem to them the most meet, and these are not natural born, but strange and foreign men, enemies of our republic of our people, because as such like enemies they provoke others to damage, burn and set houses on fire, not so much with a zeal for justice as the greed of theft. ${ }^{13}$

The final phrase alluded to the sack of Medina del Campo, an attack carried out under orders of the Royal Council headed by Adrian of Utrecht using native forces under Antonio de Fonseca. Initially, Castile's Cortes had refused to render homage to their new king until he had sworn to observe the laws of the kingdom, promised to learn Castilian, and admit 'castellanos y españoles' to his court and retinue. Language, respect for the rule of law and representation through inclusion within the king's household were key conditions for his and later Philip's acceptance. That 'castellano' and 'español' were not synonymous at this point is clear from the dual formulation throughout the document, implying that while Aragonese, Valencian or Andalusian subjects might be generalized in this way, the Castilian still warranted a specific denomination. Castrillo emphasized: 'What could be more worthy of marvel than strange people with diverse languages, who divinity divided due to man's pride, to see them in harmony brought together for the good conversation of men!'14 Civic, republican accounts of power rooted in natio represented a significant challenge to international dynastic politics, which the comuneros clearly understood as abrogating sovereignty and compromising indigenous liberties. ${ }^{15}$ The geographical scale of Habsburg authority depended on allegiance to a bloodline increasingly alienated from its territorial origins. Personal fealty and allegiance were made to do more and more ideological work, as the figure of the monarch increasingly

13 Castrillo, Tractado de república, pp. 7-8: 'las novedades y los consejos más escandalosos les parecen más saludables, y estos tales no son nuestros naturales, sino hombres peregrinos y extranjeros, enemigos de nuestra república y de nuestro pueblo, porque como tales enemigos provocan a las otras gentes a dañar, a quemar y encender las casas, no tanto con celo de la justicia como con cubdiçia del robo' (emphasis added).

14 Castrillo, Tractado de república, p. 21: ‘QQue cosa puede ser mas digna de maravilla que las gentes extrañas y de diversas lenguas, las cuales dividio la divinidad por la soberbia de las gentes, verlas concertadas por la buena conversacion de los hombres!'

15 Fernández-Santamaría, The State, War and Peace, pp. 11-30. 
disappeared into invisibility; the itinerant monarchies of Ferdinand, Isabella and Charles V gave way to the static rule of Philip II and then retreated into the courtly worlds of Philip III and IV, hemmed in by the great favourites, Lerma and Olivares. In the New World, obeisance was done to the monarch's portrait as proxy, depicted in Juan Bautista Maíno's famous 1635 painting of the recapture of Bahía (1625).

All early modern states experienced tensions between centralizing, idealizing versions of power rooted in natural, quasi-familial relations and the realities of the jealously guarded privileges and customs of local elites. The centre needed to appeal simultaneously to multiple audiences, signalling their particular interests' favoured status, while avoiding stimulating common cause between groups on the periphery, for example, in shared religion or oppression. Multivocal communication and the attempt to appeal to different groups simultaneously, to be all things to all people, placed increasing strain on the centre, as the balance of power between different groups on the margins shifted and changed. ${ }^{16}$ In this period, universal appeal, an appealing universality even, became increasingly difficult to sustain in the face of growing tensions and rivalries between groups competing for favour and recognition from a solitary centralized monopoly on economic rewards or mercedes. Mutual dependence, interconnection and shared interests between the centre and local ruling groups created incentives for cooperation and collaboration, while competition, disconnection and divergent interests among those groups and the centre, between them and the areas they controlled or between each other stretched the centre in different directions. An endemic tension between centrifugal and centripetal forces bedevilled attempts to create either greater unity or devolution. Jurisdictional conflicts could be reassuring signs of the importance of local interests to the monarchy. However, they occupied much of its energies and distracted from a grand strategy, which would have inevitably had winners and losers.

One area where these competing interests were often keenly felt was trade. Transnational but often key to local prosperity, it was at times crucial in order to access skills and resources, while at other times it signified foreign competition. A ban on trade with England did not stop John Hawkins from trading with everywhere from the Isle of Margarita to Cartagena in the late 1560 s, selling the shipload of black slaves he had acquired with Portuguese help. In 1545, Robert Reneger's piratical seizure of the silver ship, 
San Salvador, goaded Philip into imposing an embargo on English trade. His officials in Seville, however, quickly reminded him that this would be counterproductive:

if the said Englishmen's goods are embargoed they will not come and trade as they have been accustomed to do because it is they who principally buy the greater part of the wines and oils from these areas and in order not to cause great damage, which will affect your majesty's royal income as much as your subjects and these towns who live from and wholly depend on their harvests, your highness might best be served by ordering its suspension. ${ }^{17}$

Local Andalusian interests outweighed the affront and violation of political treaties between England and Spain. The functionary underlined the identification of the region's economic interests with Philip's own over and above any wider power struggle, political or strategic interest. Here the locale exploited tension between economic and political self-interest to persuade the monarch that protectionist policies would be damaging to his own finances.

Different visions of belonging flowed from constructions of political groups as either civic or ethnic. On the one hand, cities were the principal locus of vecindad, neighbourhood or community, associated with the enjoyment of certain freedoms or rights. The urban was porous, as a destination and itinerary, linking spaces together. On the other hand, the body of the commonwealth was an abstraction from place, locating identity transhistorically in bloodline or birth. For Annabel Brett, the city exposed:

a critical early modern tension between the commonwealth as a situated space and as a body that of its essence defies situation. It is here that the two senses of civitas, a city like Paris and a commonwealth like France, collide. The first kind of city is firmly situated with the walls of the urbs. It welcomes or excludes strangers at its gates, and travel is primarily perceived as being between cities in this sense. ${ }^{18}$

17 Transcribed in Appendix D of Connell-Smith, Forerunners of Drake, p. 244; original at Archivo General de Indias, Contratación, leg. 5103: 'como se enbargan los bienes de los dichos yngleses no vienen a contratar como solian porque ellos principalmente conpraban todos los mas de los vinos y azeytes de todos estos pueblos y al no hazerse el mucho daño que se rrecibe asy en las rrentas rreales de su magestad como sus subditos y los destos pueblos que biben y se valen de sus cosechas y si vuestra alteza fuese seruido podria mandar suspender el enbargo'. 18 Brett, Changes of State, p. 7 (emphasis in the original) and see pp. 35, 118, 168. 
The rights to travel and discourse were critical in the philosophical justifications for Spanish possessions in the Americas. Francisco de Vitoria's lecture on the 'Indies' dismissed all the arguments for the conquest one by one, returning at the very end to suggest that the ius communicandi or ius peregrinandi, the right to travel, use harbours and rivers, trade and settle 'unoccupied' territory were the only possible grounds for the Spanish presence in the Americas beyond the subsequent right of self-defence. In discussing the proposition that 'the Spaniards have the right to travel and dwell in those countries, so long as they do no harm to the barbarians, and cannot be prevented by them from doing so', Vitoria elaborated on a series of propositions, including that the 'Spaniards may lawfully trade among the barbarians', that 'if there are any things among the barbarians which are held in common both by their own people and by strangers, it is not lawful to prohibit the Spanish from sharing and enjoying them', that 'if children born in the Indies of a Spanish father wish to become citizens of that community, they cannot be barred from citizenship or from the advantages enjoyed by the native citizens born of parents domiciled in that community'. ${ }^{19}$ In his conclusion to the whole essay, Vitoria wrote, 'Look at the Portuguese, who carry on a great and profitable trade with similar sorts of peoples without conquering them.'20 Their maritime (trading as opposed to territorial) empire offered an alternative model, one in which tribute and symbolic overlordship stood in for territorial control.

The controversial nature of this right upon which Vitoria built his argument is apparent from the disagreement that erupted amongst his pupils surrounding poor relief and schemes that made charity a public or civic duty. State-controlled poor relief sought to control and limit subjects' right to travel. Supporters averred that vagabondage was purposeless travel, movement for its own sake, existing in the interstices between civic spaces, in a wilderness beyond the law, while opponents argued forcibly that tying individuals to the places of their birth enacted an enforced genealogical, bounded concept of community that ran counter to the universality of natural law and human nature. Domingo de Soto argued from this universal human community for a 'juridical cosmopolitanism', whose implication was a universal right to travel as well as the porosity of any bordered commonwealth and in this sense its spatial contingency. The rights of beggars to wander were part of a broader right to travel and traverse juridical spaces 
without hindrance. ${ }^{21}$ Debates about the law of nations and the law of nature revolved around the limits and extent of human sociability, the fundamental connectedness of all human society. Hugo Grotius's work on the freedom of the seas and de iure belli, for example, constructed the pursuit of self-interest as logically prior to the love of others, from which flowed an insistence not only on free trade and travel but free migration and settlement.

These cosmopolitan ideas, along with growing levels of mobility and trade, challenged constructions of political communities rooted in natio. Legally, being a natural, to pick up on Castrillo's term, could come about through birth, marriage, honorific title, inheritance or ten years' residence. Sometimes even the love of the community demonstrated in acts contributing to the common good were sufficient to evidence citizenship. Many of these modes of acquiring naturalized status had nothing to do with birth. The terms 'natural' and 'vecino' mediated in this sense between belonging to a community or people. ${ }^{22}$ In Castile being a natural was often invoked to distinguish between subjects born there and foreign-born subjects of the 'Spanish' king, such as Catalans, Aragonese, Italians or even at some points Englishmen. As a dynastic state, Spain was composed of many nations and the formation of a Spanish people, involved 'the superimposition of a "Castilian" identity on distinct regional identities. ${ }^{23}$ However, the desire to retain distinctions amongst Iberian peoples remained strong, surfacing in the great jurist Juan de Solórzano Pereira's Politica Indiana from 1647, which asserted that 'we should classify the Aragonese as foreigners, just as we do the Portuguese, Italians and Flemish'. ${ }^{24}$ Only Castilian subjects were in principle permitted to settle and trade with the Americas. Nevertheless in the context of emigration to the New World, Spaniard came to encompass all Iberians and often subjects from beyond the peninsula. The progressive conflation of Castile with Spain led to what has been described as the Castilianization of the Spains, a process that paralleled the Hispanization of the Habsburg monarchy and the Catholicization of the Iberian Peninsula. ${ }^{25}$

If there were internal pressures bubbling up from the dominance of Castile in Iberia, the conflation from outside of all Philip II's subjects as Spaniards reinforced the undiscriminating confusion implicit in the term. 'Spain' and the 'Spanish' were defined from outside with little distinction

25 Thompson, 'Castile, Spain and the Monarchy', pp. 137-141. See also Kamen, Imagining Spain, pp. 16-21, and Feros, Speaking of Spain, pp. 12-47. 
made between the various peoples who made up the Hispanic monarchy. As Henry Kamen has suggested, the empire came to define the nation. ${ }^{26}$ The image of Spain and the Spanish that evolved often revolved around understandings of its empire and colonialism, antagonistic readings of competitors who had a stake in attributing its bloody genesis and inevitable decline to backward, superstitious and hypocritical religiosity and its secular counterpart, corrupt and tyrannical, absolutist rulers. This anti-Spanish mythology constructed from the outside is elegantly captured by the term 'exomorphism' and is an integral part of the complex and controversial historiographical processes that coalesced in the late nineteenth century as the Black Legend. The dialogue between self-image and the reflections of others has been a major, distinctive feature of Spanish historiography since the early modern period. ${ }^{27}$

Hispanophobia and Hispanophilia were both integral to this tradition. Spain's power made her the inevitable target at which the whole world shot her arrows. What critics took Spain to be frequently inflected the nature of both their admiration and anxiety. The example of Spain, as the preeminent Catholic power in Europe, was a model for emulation and a power to be feared and fought. A central aspect of both Spain's self-image and its perception from outside, especially in religiously hostile Reformed parts of northern Europe like England, the rebellious provinces in the Netherlands and parts of Germany, was, of course, Catholicism. In a contribution to a recent popular collection of essays titled Histories of Nations, Enric Ucelay-Da Cal posits 'crusading religion [as] a strong unifying element' and concludes that apocalyptic mortality in the Americas gave Spain a reputation for 'fierceness and cruelty' and 'an inflated sense of their own importance and valour, which sadly they have never outgrown'. ${ }^{28}$ Such a construction albeit found in a work of general history is revealing about how far Spanish identity continues to be constrained and contained within a limited and caricatured view of religion's particular importance in defining early modern Spain. The land of convivencia, even taking into account the tendency to romanticize what living together actually looked like, did not move from being a multifaith, multiethnic and multicultural society to one of homogenous Catholic hegemony, even in the century that concerns us here. In his book Neighboring Faiths, David Nirenberg drew attention to 'the importance of

26 Henry Kamen, Imagining Spain, pp. 21-24.

27 Rodríguez Pérez, Sánchez Jiménez and Den Boer, España ante sus críticos. See the superb and comprehensive consideration of this phenomenon in Sánchez Jiménez, Leyenda Negra.

28 Ucelay-Da Cal, 'Spain', p. 77. 
group identity formation in constant relation to neighboring communities, in which Christians, Muslims, and Jews define their own identities through acts of measuring, distancing, and sometimes appropriating aspects of other communities' formations, arguing that the persecution unleashed in 1391 would 'produce a revolution in the social and theological understanding of what it meant to be Christian.' ${ }^{29}$ Here he makes an argument that entirely uniform religious communities experience their faith in submerged and less conscious ways, difference producing a more sharply defined sense of being Christian, but also a contextual one that produced potential points of contact with other faiths. Diversity produced a sharpened awareness of difference and its importance, while simultaneously foregrounding threatening similitude. This sense deepened through the crucial role of evangelization in the justifications for Spanish incursions into the Americas and the fracturing of religious consensus in Europe.

Crusading Catholicism became an integral part of the image cultivated by Habsburg monarchs and provided a rallying point for myriad subjects, although not others. While intended to provide a unifying element to farflung kingdoms separated in space and time, it glossed over religious wars in its European territories and essential religious divisions at home. Evangelical polemicists, picking up on earlier Italian insults, taunted Spaniards for their 'racial' impurity. In The Coppie of the Anti-Spaniard, Philip II was described as a 'demie Moore, demie Jew, yea demie Saracine', a 'Saracin Castilian', while the Spanish were of 'Mauritanian race', who the rest of Europe should 'with one breath to goe and abate the pride and insolencie of these Negroes' $3^{30}$ The use of the term 'race' in this example underlines how different early modern conceptions of it were. Here it is understood in a religious sense, a concomitant of faith rather than geography. Free black Spanish subjects underlined in legal depositions their status as cristianos viejos and thus their membership of the political community, something the authorities confirmed by respecting their status as naturales of Castile. ${ }^{31}$ One freed black Spanish subject, who had served in a convent, argued against discrimination based on colour, contending that 'beneath a black pelt an ennobled spirit can be found' and 'that there is no white person, no matter how beautiful who is not capable of offending his Lord and black no matter how ugly

29 Johnson, 'Review of David Nirenberg', p. 2.

$3^{0}$ The Coppie of the Anti-Spaniard, sigs. B2r, D2v, E1r and F1r. See discussion of this in Fuchs, Exotic Nation, esp. p. 123 .

31 See the fascinating article on this by Ireton, "'They Are Black of the Caste of Black Christians", p. 6og. 
who is unable to please and appease him with his good service and work'. ${ }^{2}$ Religion's transcendence of blood also had profound implications for the social order more broadly.

Obsession with bloodline, embodied by the notorious estatutos de limpieza de sangre and their exclusion of anyone with a taint of non-Christian blood in their ancestry from royal posts, the military orders and certain ecclesiastical roles, were paradoxically often used to undermine aristocratic patronage networks and privilege. These divisive exclusions have too frequently and simplistically been seen as symptoms of intolerance, when in fact they were often invoked only in specific factional struggles in order to bypass class hierarchy. This was certainly the case for one of the best known instances, that of Cardinal Juan Martínez Silíceo in the Cathedral chapter of Toledo. ${ }^{33}$ It is hard not see the persecution of religious minorities, forcible conversions and subsequent inquisitorial pursuit of Judaizers and crypto-Muslims along with the somewhat ineffectual estatutos as symptoms of attempts to whitewash Spain's international reputation, creating the proper imagined unity and religious homogeneity of its crusading imperialism. Their reputation for religiosity was perhaps embraced even more after the great era of religious renewal was already over. Religion's role as a defining aspect of Spanishness in this sense always flowed from troubled political relations. England and Spain had slipped into open war as confessional divides hardened in the wake of Trent, culminating in the series of naval expeditions in the $1580 \mathrm{os}$ and 1590 s.

Looking back over this troubled relationship the translator Francis Rivers asserted in his dedication of Antonio Ortiz's Relation concerning the visit of Philip III and Margarita de Austria to the English College in Valladolid, a training seminary for priests for the glorious reconversion of England, that:

[T] he assurance of good meaninge, and knowen continuance of good will in them that were wont to be our best frends, though of late prouoked to be our enemyes, should encorage vs much to Peace, and to renew the old confederations which our forefathers with so great wisdome procured so many ages, with so great benefit of the land, especially with those in whom yet vnder the profession of hostility and exercise of war, wee fynde

$3^{2}$ This intriguing document was transcribed, analysed and published by Glyn Redworth: 'debajo de negro pellejo se encierra ennoblecido animo', 'que no ay blanco, por hermoso que sea que no pueda ofender a su Señor y negro por feo que no le pueda aplazer y agradar con sus buenos seruicios y obras' ('Mythology with Attitutude?', pp. 63 and 66).

33 Samson, 'The Adelantamiento of Cazorla', p. 819. 
far better harts and more true affection to our Country and Countrymen (as in this occasion may be sene) then in others, whom with great care and cost we labor (I feare in vayne) to make of old enemyes, new frends. ${ }^{34}$

His argument that the signs of favour shown to English Catholic fugitives in Spain was a symptom of true affection aimed to persuade Elizabeth I's Lord Chamberlain, just a few years before the Treaty of London did indeed renew old confederations, that in the great strategic balance of power in Europe, England would always be better off siding with Spain. Despite anti-Spanish propaganda like The Coppie of the Anti-Spaniard, the famous satirical scene in Ben Jonson's The Alchemist (1610) made clear that English admiration for everything Spanish could verge on the gushingly embarrassing:

$\begin{array}{ll}\text { Kastril. } & \text { To be a Countess, say you? } \\ \text { Face. } & \text { A Spanish Countess, sir. } \\ \text { Pliant. } & \text { Why? Is that better than an English countess? } \\ \text { Face. } & \text { Better? 'Slight, make you that a question, lady? } \\ \text { Kastril. } & \text { Nay, she is a fool, Captain, you must pardon her. } \\ \text { Face. } & \text { Ask from your courtier, to your Inns of Court-man, } \\ & \text { To your mere milliner: they will tell you all, } \\ & \text { Your Spanish jennet is the best horse. Your Spanish } \\ & \text { Stoop is the best garb. Your Spanish beard } \\ & \text { Is the best cut. Your Spanish ruffs are the best } \\ & \text { War. Your Spanish pavan the best dance. } \\ & \text { Your Spanish titillation in a glove } \\ & \text { The best perfume. And, for your Spanish pike, } \\ & \text { And Spanish blade, let your poor Captain speak. }{ }^{35}\end{array}$

The passage moves from status symbols, synecdoches of courtly sophistication, to allusions to Spanish military dominance. The sycophantic admiration, however, is undercut by the comic, satirical context. These images of fine horses, clothes, grooming and dancing sit paradoxically alongside popular literary translations from the period highlighting picaresque poverty and the deprivation and degradation of Spanish subjects.

The picaresque genre dramatized the temporal and spatial mobility of early modern subjects, their existence beyond patriarchal surveillance and control, moving across boundaries and borders, vagrant and journeying. 
Beyond productive, dignifying labour lay a freedom and leisure associated with power. The literature of the picaresque was a fiction of counterexemplary journeying, a dark reflection of imperial crossing. Restless travel became a defining feature of Spain in the light of the global, interconnected world it had brought into being. This development transformed the peregrino or pilgrim from being a figure invoking Christian concepts of charity and enjoined hospitality into a symbol of threatening foreign otherness. Vagrancy and poor laws banned foreign pilgrims from courts, just as they placed the fundamental moral obligation of charity into the hands of the state, making municipal authorities responsible for regulating begging, the impoverished and starving. Stifling bureaucratic attempts to control movement, police borders and frontiers, and to assert political claims concerning where one place began and another ended countered a spirit of adventure and freedom dramatized in literary fiction. If errancy is a defining element of modernity, Spain's most famous novelistic character, Don Quijote incarnates those travails that go nowhere, a meditation on the local inhabiting the global, a self-conscious parochialism reflecting comically on the universalism firing global empire. This toothless, poor and deluded social climber from a decaying backwater incarnates a new form of elusive subjectivity, defined by novelistic narrativity the 'movement towards' characteristic of desire. This iconic economic migrant, travelling to put his free-lance to good use in service of the king, reflected all the problems of global scale and the neglect of home.

In an exploration of the connected and disconnected history of early modern Portugal's encounters with Sri Lanka, Zoltán Biedermann points to the importance of scale, not just from the perspective of distance, pointing out that 'in an era of material-based communications the global and the local tend to inhabit different temporalities'. ${ }^{6}$ For Spain, periods of restless expansion and mobility brought open, universalist ideas to the fore, even as they struggled to abolish internal division and difference. Pluralism competed with Castilianization. Attempts to enforce religious conformity addressed jibes circulating in Italy, Germany and the Low Countries about the Semitic taint infecting the Spanish natio, but also competed with the very instability of this category in the face of porous and ill-defined borders. As we have seen, what fell inside/outside the purview of Spain shifted and changed across the sixteenth and early seventeenth centuries. Until 1612, many Spanish subjects (the moriscos) displayed behaviours that could be characterized as culturally Islamic and there were even a small number of 
Spanish Muslims remaining in the peninsula into the 1580 os. ${ }^{37}$ These exotic features were remarked on by European travellers throughout the period.

The notion of the polycentric implies centres interlinked and interacting with each other. However, they were grouped and conjoined in different ways, with different levels of spatial and political interconnectedness, and greater or lesser extents of internal integration and homogeneity..$^{38}$ The tendency to monumentalize Spain skates over this de facto complexity. The paradox was that as the 'empire' grew it became less and less Spanish, leading as arbitristas frequently noted to the depopulation of Castile, exhausting the stock of this gens. The political compromises underlying Spain's creation as a territorial state involved the centralization of power in the hands of the monarchy and the marginalization of its representative cities. A backlash against this process is still present in the tensions between centralizing and devolution. ${ }^{39}$ These relations between the universal and the particular, between the global and the local, define the necessary and yet contested cosmopolitanism that made Spain's 'empire' possible. Early modern Spain was at once defined by the universal and global, by a cosmopolitanism that moved beyond the local and particular, but simultaneously celebrated that same locality and particularity in the process of erasure. The Viaje de Turquía opens with just such an image of rooted fixity, situating the beginning of the journey at the shrine of Spain's patron saint, Santiago, where one of the three interlocutors recounts that 'The most delightful way out of the city and the most pleasing one for me, greatest for recreation is the French road, as much for the freshness of its groves as for the enjoyment of the diversity of peoples, variety of nations, multitude of languages and dress that Saint James makes our guests on this his pilgrimage. $4^{40}$ The scene is one of egress, on the way to France, celebrating multiplicity of dress, language and peoples, human diversity in this one place. The problem of inclusion/exclusion is typified by the contrast between Nicolás Antonio's

37 Although the evidence is problematic, the so-called young man from Arévalo was collecting funds in Zaragoza to undertake Hajj in the mid-sixteenth century (see Harvey, Muslims in Spain). Trevor Dadson made this question the subject of a recent keynote at 'Iberian (In)tolerance: Minorities, Cultural Exchanges and Social Exclusion in the Middle Ages and Early Modern Era', LAHP Student Conference, 8-9 November 2018.

38 Cardim, et al., 'Introduction', pp. 3-10, p. 4.

39 The key bibliography in this field includes Hillgarth, The Mirror of Spain, and Fuchs, The Poetics of Piracy.

40 Villalón, Viaje de Turquía, fol. 11r.: 'La más deleitosa salida y más a mi gusto de toda la ciudad y de mayor recreación es ésta del camino francés, así por la frescura de las arboledas, como por gozar de la diversidad de las gentes, variedad de naciones, multitud de lenguas y trajes que señor Santiago nos da por huéspedes en este su peregrinaje'. 
Biblioteca Hispana Nueva, a grandiose bibliographical project to underline the status of Spanish culture that listed amongst the nations figuring in the literary treasury Alavans, Asturians, Canarians, Cantabrians, Catalonians, Portuguese, and Brazilians and estatutos de limpieza de sangre that sought to find the defining quality of identity in distant, genealogical pasts. ${ }^{41}$

Phobias can often be philias in disguise. Filiation between Spain and its critics can be gauged from the scale of translation and the appropriation of its culture, an intercultural traffic that has been consistently marginalized in the literary histories of many countries, including England. ${ }^{42}$ The partial truths of the Black Legend that reflect the genuine brutality of conquests in the Americas but are used as universal condemnations of all 'Spaniards' are the hardest to combat because they wrap truth in packets with fiction, exaggeration, generalization and fabrication. By lashing falsehoods tightly to indisputable facts, complex work is necessary to disentangle the two, darker elements inevitably staining and tainting the whole. Being Spanish in the early modern period was trapped between conflicting axes of political compositeness and integration, movement and mobility, fixity and rootedness, pride and shame. Visions of movement veered between contamination and cosmopolitanism, rejection and expulsion, emulation and admiration, as Barbara Fuchs has argued in relation to England's disavowed emulations of Spain. The composite monarchy sat at the crossroads where vernacular literary cultures coalesced in this period, in transnational flows across borders and boundaries, both religious and political, that were simultaneously being constructed. Being Spanish in the early modern world meant, on the one hand, mobility, the ability to evade singular definition, a transnational melange of influences, trade and exchanges, counterbalanced by an intense localism. Criollos like Juan de Espinosa Medrano would soon challenge the centre's interest for and in the periphery: 'Belatedly it seems I undertake this enterprise: but we crioles live very far away and the wings of interest do not convey them, Spanish things visit us lazily. 43 Tensions between centre and periphery are apparent in his defence of Spain's prince of poets, the belatedness of this response and the interest that covers and bridges the distance, an

41 Feros, Speaking of Spain, pp. 64-65; Antonio, Bibliotheca Hispana.

42 See my English-Spanish translations database: http://www.ems.kcl.ac.uk/apps/index.html. See also Rodríguez Pérez's contributions in this volume.

43 Espinosa Medrano, Apologético en favor de Don Luis de Gongora, 'Al lector', sig. d2 r.: 'Tarde parece que salgo a esta empresa: pero vivimos muy lejos los criollos y, si no traen las alas del interés, perezosamente nos visitan las cosas de España'. 
interest that is both self-interested and about what is interesting. Even in the seventeenth century, it proved easier for the municipal authorities in Seville to buy grain from North Africa than to import it from Castile. Spain was first and foremost conceptualized as an empire, self-confident in exactly the same measure as it was critical and reflective about the costs of empire. From the outside, its identity seemed self-evident, erasing internal differences, the multicultural, plurilingual, yet its actual political differences were never, as for so many other nations, fully resolved. Being Spanish in the early modern era was at once expansive and open, jealous and closed. Competitors and imitators who saw themselves reflected and transformed by Spain, dissolving in their Hispanophilia, rescued themselves only by transforming this into Hispanophobia.

\section{Works Cited}

\section{Primary sources}

Antonio, Nicolás, Bibliotheca Hispana sive Hispanorum qui usquam unquamve sive latiná sive populari (Rome: Nicolai Angeli Tinassii, 1672).

Calendar of State Papers: Scotland, Vol. 1: 1547-63, ed. Joseph Bain (London: HMSO, 1898).

Castrillo, Alonso de, Tractado de república (Burgos: Alonso de Melgar, 21 April 1521). Christopherson, John, An exhortation to all menne to take hede and beware of rebellion (London: John Cawood, 1554).

The Coppie of the Anti-Spaniard (London:John Wolf, 1590).

De Soto, Domingo, Deliberación en causa de los pobres (Salamanca: Juan de Junta, 1545).

Espinosa Medrano, Juan de, Apologético en favor de Don Luis de Gongora príncipe de los poetas líricos de España contra Manuel de Faría y Sousa, caballero portugués (Lima: Juan de Quevedo y Zarate, 1662).

Jonson, Ben, The Alchemist, ed. Elizabeth Cook (London: Bloomsbury, 1991).

Ortiz, Antonio, A Relation of the Solemnetie wherewith the Cathlike Princes K. Phillip the III and Quene Margaret were receyued in the Inglish Colledge of Valladolid the 22 of August 160o, trans. Francis Rivers (Antwerp: A. Conincx, 1601).

Villalón, Cristóbal de, Viaje de Turquía, BNE MS 3871, http://bdh-rd.bne.es/viewer. vm?id=0000079010\&page $=1$ (last accessed: $8 / 2 / 19)$

Vitoria, Francisco de, 'De Indis', in Political Writings, ed. Anthony Pagden and Jeremy Lawrence (Cambridge: Cambridge University Press, 1991), pp. 231-292. 


\section{Secondary sources}

Biedermann, Zoltán, (Dis)connected Empires: Imperial Portugal, Sri Lankan Diplomacy, and the Making of a Habsburg Conquest in Asia (Oxford: Oxford University Press, 2018).

Brett, Annabel S., Changes of State: Nature and the Limits of the City in Early Modern Natural Law (Princeton: Princeton University Press, 2011).

Cardim, Pedro et al., 'Introduction. Polycentric Monarchies: How Did Early Modern Spain and Portugal Achieve and Maintain a Global Hegemony?', in Polycentric Monarchies: How Did Early Modern Spain and Portugal Achieve and Maintain a Global Hegemony? , ed. by Pedro Cardim, Tamar Herzog, José Javier Ruiz Ibáñez and Gaetano Sabatini (Eastbourne: Sussex Academic Press, 2012), pp. 3-10.

Connell-Smith, Gordon, Forerunners of Drake: A Study of English Trade with Spain in the Early Tudor Period (Westport: Greenwood Press, 1975).

Elden, Stuart, The Birth of Territory (Chicago: University of Chicago Press, 2013).

Elliott, John H., 'A Europe of Composite Monarchies', Past and Present 137 (1992), pp. 48-71.

Espinosa, Aurelio, The Empire of the Cities: Emperor Charles V, the Comunero Revolt, and the Transformation of the Spanish System (Leiden: Brill, 2009).

Fernández-Santamaria, J.A., The State, War and Peace: Spanish Political Thought in the Renaissance 1516-1559 (Cambridge: Cambridge University Press, 1977).

Feros, Antonio, Speaking of Spain: The Evolution of Race and Nation in the Hispanic World (London: Harvard University Press, 2017).

Fuchs, Barbara, Exotic Nation: Maurophilia and the Construction of Early Modern Spain (Philadelphia: University of Pennsylvania Press, 2009).

—, The Poetics of Piracy: Emulating Spain in English Literature (Philadelphia: University of Pennsylvania Press, 2013).

Harvey, L.P., Muslims in Spain, 1500-1614 (Chicago: University of Chicago Press, 2005). Herzog, Tamar, 'Communities Becoming a Nation: Spain and Spanish America in the Wake of Modernity (and Thereafter)', Citizenship Studies 11 (2002), pp. 151-172.

-, Frontiers of Possession: Spain and Portugal in Europe and the Americas (Cambridge, MA: Harvard University Press, 2015).

Hillgarth, Jocelyn Nigel, The Mirror of Spain, 1500-1700: The Formation of a Myth (Ann Arbor: University of Michigan Press, 2000).

Ireton, Chloe, “They Are Black of the Caste of Black Christians": Old Christian Black Blood in the Sixteenth and Early Seventeenth Century Iberian Atlantic', Hispanic American Historical Review 97 (2017), pp. 579-612.

Johnson, Hannah, 'Review of David Nirenberg, Neighboring Faiths', Studies in Jewish Christian Relations 12 (2017), pp. 1-3. 
Kamen, Henry, Imagining Spain: Historical Myth and National Identity (New Haven: Yale University Press, 2008).

Muir, Kenneth, Life and Letters of Sir Thomas Wyatt (Liverpool: Liverpool University Press, 1963).

Nexon, Daniel, The Struggle for Power in Early Modern Europe: Religious Conflict, Dynastic Empires and International Change (Princeton: Princeton University Press, 2009).

Pagden, Anthony, Spanish Imperialism and the Political Imagination: Studies in European and Spanish-American Social and Political Theory, 1513-1830 (New Haven: Yale University Press, 1990).

Redworth, Glyn, 'Mythology with Attitutude? A Black Christian's Defence of Negritude in Early Modern Europe', Social History 28 (2003), pp. 49-66.

Rodríguez Pérez, Yolanda, Antonio Sánchez Jiménez and Harm den Boer, eds, España ante sus críticos: Claves de la Leyenda Negra (Madrid/Frankfurt am Main: Iberoamericana/Vervuert, 2015).

Samson, Alexander, 'The Adelantamiento of Cazorla, Converso Culture and Toledo Cathedral Chapter's 1547 estatuto de limpieza de sangre', Bulletin of Spanish Studies 84 (2007), 819-36.

Sánchez Jiménez, Antonio, Leyenda Negra: la batalla sobre la imagen de España en tiempos de Lope de Vega (Madrid: Cátedra, 2016).

Thompson, I.A.A., 'Castile, Spain and the Monarchy: The Political Community from patria natural to patria nacional', in Spain, Europe and the Atlantic World: Essay in Honour ofJ.H. Elliott, ed. by Richard Kagan and Geoffrey Parker (Cambridge: Cambridge University Press, 1995), pp.125-159.

Ucelay-Da Cal, Enric, 'Spain: Beyond the Black Legend', in Histories of Nations: How Their Identities Were Forged, ed. Peter Furtado (London: Thames and Hudson, 2012).

\section{About the Author}

Alexander Samson is Reader in Early Modern Studies at University College London in the Department of Spanish, Portuguese and Latin American Studies. He has published widely on the influence of Spanish culture in early modern England, festival texts, early colonial history, the marriage of Philip II and Mary I, historiography and royal chroniclers, Lope de Vega and Cervantes. He collaborated on the NWO project 'The Black Legend and the Spanish Identity in Golden Age Spanish Theatre (1580-1665)', publishing two essays in the resulting volumes. His next project focuses on intercultural interactions between England and Spain and Hispanophilia. 
